\title{
RANCANGAN UNDANG- UNDANG TENTANG SISTEM PERBUKUAN NASIONAL
}

\section{B.P. Sitepu}

Kemajuan pendidikan suatu bangsa dapat diukur antara lain dari kemajuan industri buku yang dimilikinya. Pendidikan yang maju didukung oleh industri buku yang maju pula. Akan tetapi kemajuan industri buku di Indonesia belum berkembang dengan baik. Secara jumlah dan mutu, pengarang/penulis, penerbit, percetakan, penyalur/distributor buku serta masyarakat pembaca, belum memadai di bandingkan dengan negara-negara maju bahkan antar negara di kawasan Asean sendiri. Buku baru yang diterbitkan di Indonesia mencapai rata-rata 6000 judul buku termasuk di dalamnya hasil terjemahan. Oleh karena itu tidak mengherankan kalau buku-buku baru terbitan Indonesia tidak banyak terlihat di perpustakaan di Indonesia. Banyak siswa, mahasiswa, guru, dosen, dan peneliti mengalami kesulitan menemukan buku-buku terbitan Indonesia sebagai referensi.

Rendahnya jumlah terbitan buku baru tidak terlepas keadaan pengrang/penulis, penerbit, dan percetakan serta masyarakat pembaca yang belum kondusif mendukung perkembangan industri buku di Indonesia. Hak cipta pengarang/penulis belum terjamin dengan baik, royalty yang tidak memotivasi, serta maraknya pembajakan buku mengurangi kegairahan dan semangat menulis. Mahalnya harga buku dalam tata niaga yang belum profesional serta sulitnya memperoleh buku di daerah-daerah tertentu tidak mendorong pertumbuhan minat dan kebiasaan membaca untuk mewujudkan masyarakat yang gemar dan gandrung membaca.

Dalam pengadaan buku pelajaran untuk sekolah tidak jarang terjadi komersialisasi sehingga orangtua mengeluhkan pergantian buku pelajaran setiap tahun pelajaran baru dengan harga yang lebih tinggi dari harga di pasar. Pembelian buku dengan menggunakan dana APBN atau APBD oleh sekolah atau Dinas Pendidikan belum sepenuhnya didasarkan pada kepentingan peserta didik dalam proses belajarmembelajarkan.

Kondisi seperti yang disebutkan di atas mendorong Departemen Pendidikan Nasional melalui Pusat Perbukuan memprakarsai menyusun Rancangan UndangUndang (RUU) tentang Sistem Perbukuan Nasional (Sisbuknas). Proses penyusunan yang mengikutsertakan kalangan pengarang/ penulis dari berbagai organisasi profesi, penerjemah, penerbit (IKAPI), percetakan, toko buku, perpustakaan, pengamat perbukuan, serta akademisi telah berhasil menyusun Pokok-Pokok Pikiran serta Naskah Akademik RUU tentang Sisbuknas. Oleh karena banyaknya komponen yang perlu diatur dalam RUU ini maka proses penyusunan yang dimulai bulan Desember 2005 itu masih terus berkembang dan memperoleh masukan dari berbagai pihak.

RUU ini mengatur tentang hak dan kewajiban Pemerintah, pemerintah daerah, masyarakat, penulis/ pengarang, penerjemah, penya- dur, penerbit termasuk penerbit perguruan tinggi, percetakan, toko buku, dan pengguna buku dalam mengem-bangkan industri buku di Indonesia. Di samping itu RUU ini juga mengatur tata cara penulisan, penerjemahan, penerbitan, pencetakan, penyaluran, tata niaga buku termasuk ekspor dan impor, serta pemanfaatan buku.

Oleh karena RUU ini masih dalam tahap penyusunan dan belum disosialisasikan, maka diharapkan semua pihak yang langsung terkait seperti penulis/pengarang, guru, dosen, siswa, mahasiswa, dapat memberikan sumbang pikiran/ pendapat ke Pusat Perbukuan Departemen Pendidikan Nasional, Jl. Gunung Sahari Jakarta Pusat. Diharapkan, RUU ini dapat dibahas dan disetujui oleh DPR RI pada tahun 2007.

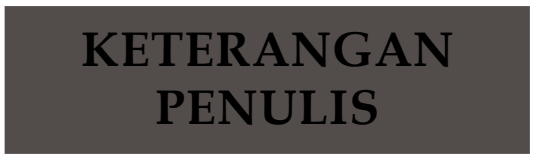

Dr. B.P. Sitepu, MA, lahir di Berastepu, Sumatera Utara, Juni 1948. Menyelesaikan pendidikan program S1 jurusan pengajaran Bahasa Inggris di IKIP Negeri Jakarta (1975), S2 bidang Perencanaan Pendidikan (Organisasi, Media, dan Inovasi) di Macquarie University, Sidney, Australia (1979) dan S3 di bidang Teknologi Pendidikan di IKIP Negeri Jakarta (1994). Menjadi tenaga pengajar tetap di Universitas Negeri Jakarta dengan jabatan Lektor Kepala (2001) dan sebelumnya pegawai negeri sipil di Departemen Pendidikan Nasional (1976-2001). 